\title{
Differences in the glucocorticoid to progesterone receptor selectivity of inhaled glucocorticoids
}

\author{
M. Issar*, S. Sahasranaman*, P. Buchwald ${ }^{\#}$ and G. Hochhaus*
}

ABSTRACT: Due to the high affinity of new inhaled corticosteroids (ICS) towards the glucocorticoid receptor (GR), and because of the similarities between the binding domains of the GR and the progesterone receptor (PR), the present study focused on assessing the relative binding affinities (RBA) of glucocorticoids (systemic and ICS) to PR (RBA ${ }^{\mathrm{PR}}$ ). By comparison with the affinities towards the GR (RBA ${ }^{\mathrm{GR}}$ ) the binding selectivities were also assessed.

In general, the selectivity of the investigated glucocorticoids showed a decreasing trend with increasing lipophilicity. When orally administered, less lipophilic glucocorticoids showed the highest selectivity, with $R B A^{G R} / R A^{P R}$ ratios of $1,375,760$ and 476 for betamethasone, beclomethasone and dexamethasone, respectively.

For ICS, mometasone furoate, the most lipophilic steroid, was the least selective (1.1), followed by beclomethasone monopropionate (9), fluticasone propionate (12), triamcinolone acetonide (18), mometasone (25) and budesonide (44), which shows the highest selectivity among inhaled glucocorticoids.

In conclusion, the present study revealed that there are differences in selectivity among commercially available glucocorticoids. Future clinical studies are needed to investigate whether the high affinity of some of the investigated glucocorticoids to the progesterone receptor is of clinical relevance.

KEYWORDS: Inhalation therapy, glucocorticoids, glucocorticoid receptor, receptors, side-effects

I nhaled corticosteroids (ICS) are the drugs of choice in the treatment of allergy and asthma.

The newer ICS show high potencies with several-fold greater affinities to the glucocorticoid receptor (GR) than the corticosteroids used for systemic therapy. However, side-effects of ICS can be induced after absorption into the systemic circulatory system when they interact with systemic or peripheral GRs. Also, some of the endogenous glucocorticoids, such as corticosterone and deoxycorticosterone, have been reported to bind to the progesterone receptor (PR) [1]. Progesterone (PROG), in turn, has been shown to bind to the GR nonselectively [2]. This cross-reactivity of ligands between different nuclear receptors is suggestive of a close homology in binding domains between the GRs and the other members of the steroid receptor family, such as the PR [3]. Recently, functional assays conducted by AUSTIN et al. [4] have demonstrated that the glucocorticoid mometasone furoate (MF) lacks GR selectivity. As potential systemic sideeffects of other inhaled glucocorticoids could be related to the binding to the PR, it was the aim of the present study to assess the selectivity of currently used inhaled and systemic glucocorticoids towards the GR, by comparing their relative receptor affinities at the GR and the PR.

\section{MATERIALS AND METHODS \\ Chemicals}

MF and mometasone (MO) were purchased from USP and European Pharmacopoeia (Strasbourg, France). Fluticasone propionate (FP) and budesonide (BUD) were provided by GlaxoWellcome (Research Triangle Park, NC, USA) and Sicor (Milan, Italy), respectively. Beclomethasone-17monopropionate (BMP) was purchased from The European Directorate for Quality of Medicine. Dexamethasone (DEX), triamcinolone acetonide (TAA), beclomethasone (BECLO), betamethasone (BET) and PROG were purchased from Sigma Chemicals Co. (St Louis, MO, USA). The specific tritium-labelled PR ligand ${ }^{3} \mathrm{H}-\mathrm{ORG}-2058$ (specific activity $36 \mathrm{Ci} \cdot \mathrm{mmol}^{-1}$ ) and the GR ligand ${ }^{3} \mathrm{H}$-TAA were purchased from Perkin Elmer Life Sciences (Boston, MA, USA). All other chemicals and

\section{AFFILIATIONS}

*Dept of Pharmaceutics, University of Florida, Gainesville, and \# IVAX Research Inc., Miami, FL, USA

\section{CORRESPONDENCE}

G. Hochhaus

Dept of Pharmaceutics

University of Florida

Gainesville

FL 32610

USA

Fax: 13523924447

E-mail: Hochhaus@UFL.EDU

Received:

May 202005

Accepted after revision:

October 162005 
solvents were obtained from Sigma Chemicals Co. and Fisher Scientific Co. (Cincinnati, OH, USA).

\section{GR BINDING IN RAT LUNG CYTOSOL Solutions}

The various dilutions for DEX $(0.001-1.0 \mu \mathrm{M}), \mathrm{FP}, \mathrm{MF}$ and MO (0.01-100 $\mu \mathrm{M})$ were prepared in methanol.

\section{Preparation of cytosol}

The animal protocol was approved by the local Institutional Animal Care and Use Committee (IACUC) at the University of Florida (Gainesville, FL, USA). Sprague Dawley rats $(250 \pm 25 \mathrm{~g})$ were obtained from Harlan (Indianapolis, IN, USA). The rats were anaesthetised using a mixture of ketamine, xylazine and acepromazine $(3: 3: 1 \mathrm{v} / \mathrm{v})$ and were then decapitated. The lungs were removed and homogenised in eight volumes of ice-cold incubation buffer (10 mM Tris/ $\mathrm{HCl}, 10 \mathrm{mM}$ sodium molybdate, $2 \mathrm{mM} \mathrm{1,4-dithioerythritol).}$ The homogenate was incubated with $5 \% \mathrm{w} / \mathrm{v}$ charcoal suspension in deionised water for $10 \mathrm{~min}$. The homogenate was then centrifuged for $20 \mathrm{~min}$ at $40,000 \times g$ in a J2 rotor of a Beckman centrifuge to obtain the cytosol. Fresh cytosol was prepared and used for all the individual experiments.

\section{Competitive GR assay}

A $20 \mu \mathrm{L}$ quantity of the drug solution in methanol was added to pre-chilled tubes. Blank methanol was used for the determination of total binding. Nonspecific binding was determined after the addition of $20 \mu \mathrm{L}$ of $100 \mu \mathrm{M}$ unlabelled TAA $(10 \mu \mathrm{M}$ in the final incubation mixture). Subsequently, $20 \mu \mathrm{L}$ of $100 \mathrm{nM}{ }^{3} \mathrm{H}$-TAA solution $(10 \mathrm{nM}$ in final incubation mixture) was then added to all tubes. The tubes were immediately vortexed after the addition of $160 \mu \mathrm{L}$ of the lung cytosol was added followed by incubation at $4{ }^{\circ} \mathrm{C}$ for $24 \mathrm{~h}$. After incubation, $200 \mu \mathrm{L}$ of $5 \% \mathrm{w} / \mathrm{v}$ charcoal suspension (in water) was added to the tubes to remove the excess unbound radioactivity. The tubes were vortexed and $300 \mu \mathrm{L}$ of the supernatant was transferred to the scintillation vials. A 5-mL quantity of the scintillation cocktail was added and the scintillation vials were read in a liquid scintillation counter (LS 5000 TD; Beckman Instruments Inc., Palo Alto, CA, USA). For some glucocorticoids, previously determined relative binding affinity (RBA) ${ }^{\mathrm{GR}}$ values for the human GR were used because the RBA ${ }^{G R}$ values for rats correlate well with humans [5] and the experimental conditions for the binding experiments were identical.

\section{PR BINDING ASSAY EXPERIMENTS IN SHEEP UTERUS CYTOSOL \\ Solutions}

The various dilutions for the steroids used were prepared in methanol and were as follows: PROG $(0.01-100 \mu \mathrm{M})$; DEX (0.03-10000 $\mu \mathrm{M})$; BET $(0.3-10000 \mu \mathrm{M})$; MF $(0.01-100 \mu \mathrm{M})$; FP (0.01-100 $\mu \mathrm{M}) ; \quad \mathrm{MO} \quad(0.01-100 \mu \mathrm{M}) ; \quad \mathrm{BMP} \quad(0.01-100 \mu \mathrm{M})$; BECLO $(0.03-1000 \mu \mathrm{M})$; BUD $(0.01-100 \mu \mathrm{M})$; and TAA $(0.03-$ $100 \mu \mathrm{M})$.

\section{Preparation of cytosol}

A uterus from a pregnant sheep was used as the source for the $\mathrm{PR}$, as this tissue provided sufficient PRs with low nonspecific binding. The animal protocol was approved by the local
IACUC at the University of Florida. The personnel handling the tissue were equipped with personal protective equipment to prevent an exposure to Coxiella burnetii, which is normally present in sheep. All procedures involved in the homogenisation of the tissue were conducted under a hooded environment. The sheep uterus tissue was obtained from a pregnant sheep, which had been sacrificed for another experimental setup. The tissues were frozen in liquid nitrogen and stored at $-80^{\circ} \mathrm{C}$ for no more than 4 days. On the day of the experiment, the tissues were dipped in liquid nitrogen for $1 \mathrm{~min}$ and then pulverised. The tissue was homogenised further after the addition of four volumes of ice-cold incubation buffer $(10 \mathrm{mM}$ Tris/ $\mathrm{HCl}, 10 \mathrm{mM}$ sodium molybdate, $2 \mathrm{mM}$ 1,4-dithioerythritol) using a Bio Homogeniser (5 s, low speed, with 30-s cooldown period between each step). The homogenate was incubated with $5 \% \mathrm{w} / \mathrm{v}$ charcoal suspension (in deionised water) for $10 \mathrm{~min}$ to remove the endogenous progestins. The homogenate was centrifuged for $1 \mathrm{~h}$ at $40,000 \times g$ in a Beckman high-speed centrifuge using a JA-20 fixed angle rotor. The resulting aqueous supernatant (cytosol) was used on the same day of the experiment. Fresh cytosol was prepared and used for all the individual experiments.

\section{Competitive PR assay}

Competitive binding experiments were performed with the PROG ligand $\left[6,7-{ }^{3} \mathrm{H}\right]-\mathrm{ORG}-2058$ as tracer. This ligand has previously been shown to bind specifically to the PR, allowing selective assessment of the PR binding for the competitors of interests. Displacement of this tracer from the PR by unlabelled glucocorticoids was assessed in sheep uterus cytosol. Portions of the cytosol $(160 \mu \mathrm{L})$ were incubated with $20 \mu \mathrm{L}$ of $20 \mathrm{nM}$ tritium-labelled $\left[6,7-{ }^{3} \mathrm{H}\right]-\mathrm{ORG}-2058$ solution (final concentration in the incubation mixture of $2 \mathrm{nM}$ ) and the same volume of varying concentrations of the competitor (prepared in incubation buffer containing 50\% ethanol). After 24-h incubation time, the unbound ligand was removed by the addition of $200 \mu \mathrm{L}$ of activated charcoal suspension $(5 \% \mathrm{w} / \mathrm{v}$ in deionised water). The mixture was incubated for $10 \mathrm{~min}$ at $0-4{ }^{\circ} \mathrm{C}$ and then centrifuged for $5 \mathrm{~min}$ at $10,000 \mathrm{rpm}$. The radioactivity in $300 \mu \mathrm{L}$ of the supernatant was determined using liquid scintillation counting (Beckman Instruments Inc.). Nonspecific binding was determined in the presence of $2 \times 10^{-5} \mathrm{M}$ of unlabelled PROG. Nonspecific binding was always $<15 \%$ of the total binding. All determinations were performed in duplicate and the entire experiment was repeated on three different occasions.

\section{DATA ANALYSIS}

The concentration of test drug necessary to reduce specific binding of tracer by $50 \%$ (IC50) of the investigated steroids (competitor concentration necessary to displace $50 \%$ of the specific ${ }^{3} \mathrm{H}$-ORG-2058 or ${ }^{3} \mathrm{H}$-TAA from the receptor site) and the slope factors of the resulting competition curves were determined by the nonlinear curve-fitting procedure using Scientist ${ }_{\circledR}$ (Micromath, Salt Lake City, UT, USA). The data was fitted to the following maximum tracer binding (Emax) model to obtain the estimates of the specific binding by the ligand in the absence of competitor (Bmax) and IC50. The Emax model is generally used to describe competition experiments in which the receptor is in equilibrium between a constant concentration of radioactive tracer and unlabelled test substance. Increasing 
the concentration of test substance $(C)$ will displace the tracer from the receptor and result in the tracer being bound only to nonspecific binding elements (e.g. albumin). The concentration needed to displace $50 \%$ of the tracer from the receptor binding site can be used to describe the affinity of the test substance to the receptor. The total tracer binding obtained at any given competitor concentration (desintegrations per min; DPM) is given by the following equation:

$$
\mathrm{DPM}=\left[\mathrm{B} \max -\mathrm{B}_{\max } \frac{\mathrm{C}^{\mathrm{N}}}{\mathrm{IC}_{50}^{\mathrm{N}}+\mathrm{C}^{\mathrm{N}}}\right]+\mathrm{NS}
$$

NS represents nonspecific binding, and $\mathrm{N}$ is the Hill coefficient. The resulting IC50 values were transformed into RBAs relative to PROG or DEX expressed as percentage values. $\mathrm{RBA}^{\mathrm{PR}}$ and $\mathrm{RBA}^{\mathrm{GR}}$ describe the relationship between the IC50 values of the test steroid to that of PROG and DEX respectively.

$$
\operatorname{RBA}_{\mathrm{PR} \text { or GR }}^{\mathrm{TEST}}(\%)=\frac{\mathrm{IC}_{50}^{\mathrm{REF}}}{\mathrm{IC}_{50}^{\mathrm{TEST}}} \times 100
$$

The GR selectivity was defined as:

$$
\text { GR selectivity }=\frac{\mathrm{RBA}^{\mathrm{GR}}}{\mathrm{RBA}^{\mathrm{PR}}}
$$

\section{Molecular modelling}

Log octanol-water partition coefficients $(\log \mathrm{P}$, a measure of the lipophilicity of a molecule) were calculated as described previously [6]. Calculated values represent the average of three computed values: CLOGP (from ChemDraw Ultra 7.0), $\mathrm{ACD} / \log \mathrm{P}$, and $\mathrm{Q} \log \mathrm{P}$ [7]. Values calculated by this procedure were found to be in very good agreement with experimental $\log \mathrm{P}$ values, where available. Structures 1A28 (for the human PR complexed with PROG) [8], 1E3K (for the human PR complexed with metribolone) [9] and 1M2Z (for the human GR complexed with DEX) [10] were obtained from the Protein Data Bank, and are displayed using DS ViewerPro 5.0 (Accelrys Inc., San Diego, CA, USA). Corticosteroid structures (BUD, BMP, FP and MF) were individually, fully geometry-optimised using AM1 semi-empirical quantum chemical calculations [11] in CAChe 5.0 (Fujitsu, Ltd, Chiba, Japan). They were then superimposed with the receptor-bound ligands by Discovery Studio's (Accelrys Inc.) molecular overlay algorithm within ViewerPro 5.0 (Accelrys Inc.) using a targeted root mean square deviation-minimising alignment on the ring-fusion atoms of the steroid structure $\left(C^{5}, C^{8}, C^{9}, C^{10}\right.$, $\mathrm{C}^{14}$ and $\mathrm{C}^{13}$ ).

\section{RESULTS}

The RBAs of the investigated glucocorticoids to the PR and GR were determined by competition binding experiments in cytosol of sheep uterus and rat lung, respectively. The RBAs of BMP, BECLO, BET, TAA and PROG to the GR were taken from previous studies for the human GR for calculation of GR selectivity [12]. This was reasonable because the binding properties of the rat and human receptors for commercially available glucocorticoids are the same [13]. The binding curves resulting from a typical set of experiments conducted with sheep uterus and rat lung cytosol are shown in figures 1 and 2,
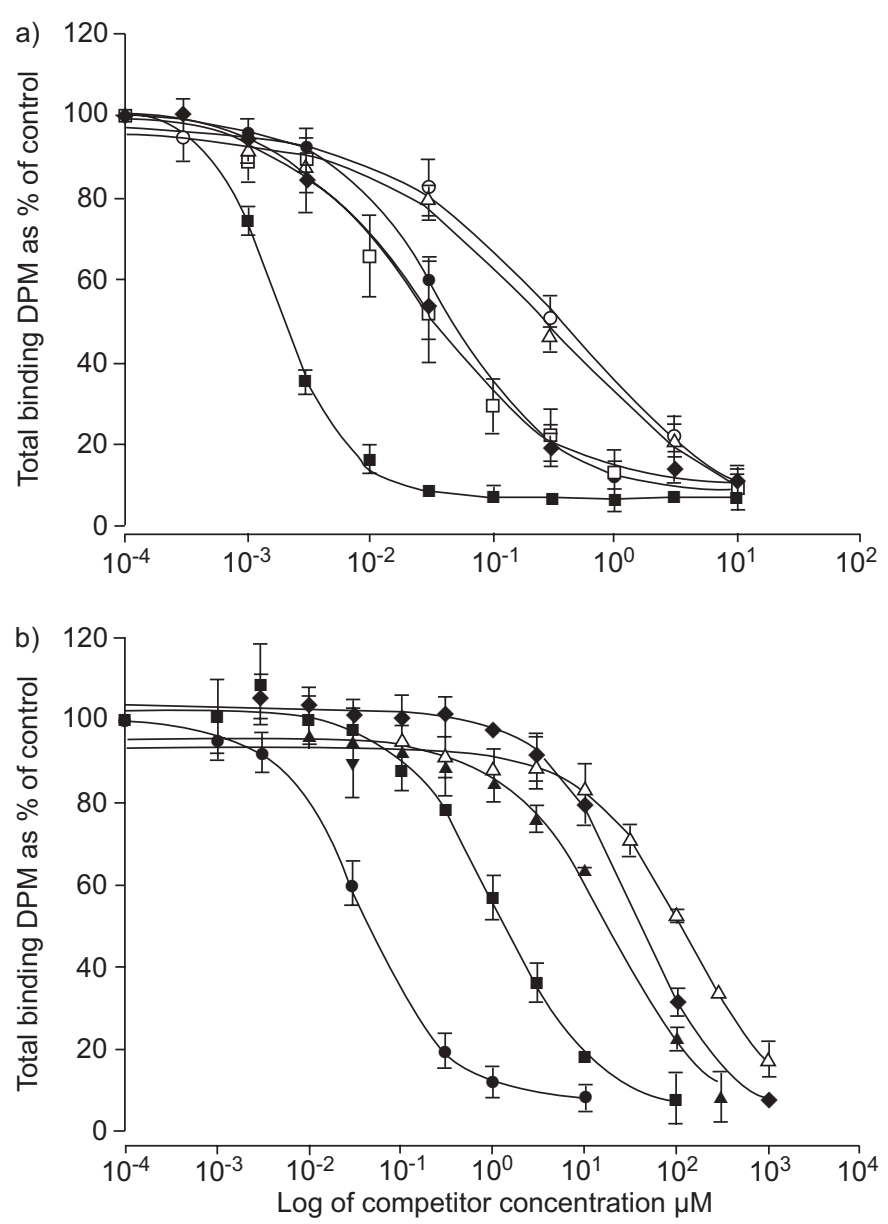

FIGURE 1. Competitive binding experiments to the progesterone (PROG) receptors in sheep uterus cytosol. a) Nonlinear regression of nontransformed data was used for the determination of concentration of test drug necessary to reduce specific binding of tracer by $50 \%$ (IC50) values of PROG (-), mometasone furoate $(\boldsymbol{\square})$, triamcinolone acetonide $(\bigcirc)$, beclomethasone-17-monopropionate $(\square)$, budesonide $(\triangle)$ and flucticasone propionate $(\bullet)$. b) Nonlinear regression of nontransformed data was used for the determination of IC50 values of PROG ( $)$, mometasone $(\boldsymbol{\square})$, dexamethasone $(\boldsymbol{\Delta})$, beclomethasone $(\bullet)$ and betamethasone $(\triangle)$. The Hill coefficient was fixed to 1 in both. DPM: disintegrations per minute.

respectively. A summary of the RBA estimates and the resulting selectivities are shown in tables 1 and 2 and figure 3 . Figure 4 shows the relationship between the logarithm of GR versus $\mathrm{PR}$ selectivity and $\log \mathrm{P}$ values with a correlation coefficient of 0.7499 for the different glucocorticoids $(n=9)$. Results of molecular models superimposing different ligands on existing crystal structures of the PR are shown for MF and BUD in figures 5 and 6 . Similar exercises were performed for DEX, BMP and FP (data not shown).

\section{DISCUSSION}

Some of the endogenous glucocorticoids have been reported to be nonselective towards the GR by binding to the PR. RAYNAUD and coworkers [1, 14] showed that synthetic glucocorticoids, such as TAA and fluocinolone acetonide, have the ability to bind to the PR indicating low GR selectivity. Recently, cellbased functional assays conducted by AUSTIN et al. [4] have shown that MF interacts with the PR as an agonist, with much 


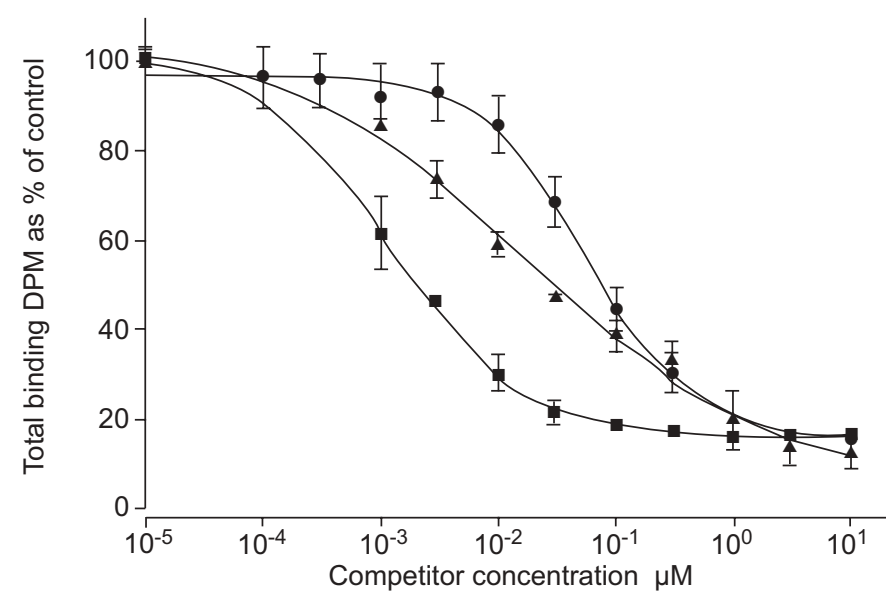

FIGURE 2. Competitive binding experiments to the glucocorticoid receptors in rat lung cytosol. Nonlinear regression of nontransformed data was used for the determination of concentration of test drug necessary to reduce specific binding of tracer by $50 \%$ (IC50) values of dexamethasone ( $)$, mometasone furoate ( mometasone $(\mathbf{\Lambda})$. The Hill coefficient was fixed to 1. DPM: disintegrations per minute

\begin{tabular}{lccc} 
TABLE 1 & $\begin{array}{l}\text { Relative binding affinities (RBA) for the } \\
\text { glucocorticoid and progesterone receptors and } \\
\text { corresponding selectivity }\end{array}$ \\
\hline Steroid & RBA $^{\text {GR }}$ & RBA $^{\text {PR }}$ & Selectivity $^{\#}$ \\
\hline BET & $55^{*}$ & 0.04 & 1375 \\
BECLO & $76^{*}$ & 0.1 & 760 \\
DEX & 100 & 0.21 & 476 \\
BUD & 900 & 21 & 44 \\
MO & 88 & 3.5 & 25.1 \\
TAA & $233^{*}$ & 13 & 17.9 \\
FP & 1800 & 152 & 11.8 \\
BMP & $1022^{*}$ & 110 & 9.3 \\
MF & 2938 & 2580 & 1.1 \\
PROG & $40^{*}$ & 100 & 0.4 \\
\hline
\end{tabular}

BET: betamethasone; BECLO: beclomethasone; DEX: dexamethasone; BUD: budesonide; MO: mometasone; TAA: triamcinolone acetonide; FP: flucticasone propionate; BMP: beclomethasone-17-monopropionate; MF: mometasone furoate; PROG: progesterone. ${ }^{\#}$ : RBA ${ }^{\mathrm{GR}} / \mathrm{RBA}^{\mathrm{PR}}{ }^{\text {; }}$ : values were obtained from previous literature [12].

higher activity than FP. The present study investigated a wide range of clinically employed glucocorticoids for their binding to the GR and PR and assessed their selectivity. GR affinities determined in the current study were in agreement with previously published work for the human and rat GR [1, 5, 13-17].

It has been previously established that the binding forces that are responsible for interaction of steroidal ligands with the GR are hydrophobic in nature, and a good correlation between the lipophilicity of the ligand and the GR RBA exists [6, 12, 13]. Interestingly, the current data (fig. 3) suggest that lipophilicity of the tested steroids also correlates with GR selectivity, with

\begin{tabular}{|c|c|c|c|c|c|c|c|c|c|}
\hline \multicolumn{2}{|c|}{ TABLE 2} & \multicolumn{8}{|c|}{$\begin{array}{l}\text { Effect of glucocorticoid substitutes on the } \\
\text { binding affinity to the progesterone (PROG) } \\
\text { receptor }\end{array}$} \\
\hline Steroid & $\Delta^{1}$ & $\Delta^{4}$ & $\alpha R$ & $\alpha \mathbf{R}_{1}$ & $\mathbf{R}_{\mathbf{2}}$ & $\alpha \mathbf{R}_{3}$ & $\mathbf{R}_{\mathbf{4}}$ & $\beta \mathbf{R}_{\mathbf{5}}$ & $\mathrm{RBA}^{\mathrm{PR}}$ \\
\hline DEX & + & + & $\mathrm{OH}$ & $\mathrm{CH}_{3}$ & $\mathrm{CH}_{2} \mathrm{OH}$ & $\mathrm{F}$ & $\mathrm{H}$ & $\mathrm{OH}$ & 0.21 \\
\hline BET & + & + & $\mathrm{OH}$ & $\mathrm{\beta CH}_{3}$ & $\mathrm{CH}_{2} \mathrm{OH}$ & F & $\mathrm{H}$ & $\mathrm{OH}$ & 0.04 \\
\hline PROG & - & + & $\mathrm{H}$ & $\mathrm{H}$ & $\mathrm{CH}_{3}$ & $\mathrm{H}$ & $\mathrm{H}$ & $\mathrm{H}$ & 100 \\
\hline MF & + & + & OCOR'\# & $\mathrm{CH}_{3}$ & $\mathrm{CH}_{2} \mathrm{Cl}$ & $\mathrm{Cl}$ & $\mathrm{H}$ & $\mathrm{OH}$ & 2580 \\
\hline MO & + & + & $\mathrm{OH}$ & $\mathrm{CH}_{3}$ & $\mathrm{CH}_{2} \mathrm{Cl}$ & $\mathrm{Cl}$ & $\mathrm{H}$ & $\mathrm{OH}$ & 3.5 \\
\hline FP & + & + & $\mathrm{OCOCH}_{2} \mathrm{CH}_{3}$ & $\mathrm{CH}_{3}$ & $\mathrm{SCH}_{2} \mathrm{~F}$ & $F$ & $\alpha F$ & $\mathrm{OH}$ & 152 \\
\hline BMP & + & + & $\mathrm{OCOCH}_{2} \mathrm{CH}_{3}$ & $\mathrm{\beta CH}_{3}$ & $\mathrm{CH}_{2} \mathrm{OH}$ & $\mathrm{Cl}$ & $\mathrm{H}$ & $\mathrm{OH}$ & 110 \\
\hline BECLO & + & + & $\mathrm{OH}$ & $\mathrm{\beta CH}_{3}$ & $\mathrm{CH}_{2} \mathrm{OH}$ & $\mathrm{Cl}$ & $\mathrm{H}$ & $\mathrm{OH}$ & 0.1 \\
\hline BUDः & + & + & $\mathrm{CH}_{2} \mathrm{CH}_{2} \mathrm{CH}_{3}$ & $\mathrm{H}$ & $\mathrm{CH}_{2} \mathrm{OH}$ & $\mathrm{H}$ & $\mathrm{H}$ & $\mathrm{OH}$ & 21 \\
\hline TAA" & + & + & $\mathrm{CH}_{3}$ & $\mathrm{CH}_{3}$ & $\mathrm{CH}_{2} \mathrm{OH}$ & $\mathrm{F}$ & $\mathrm{H}$ & $\mathrm{OH}$ & 13 \\
\hline
\end{tabular}

RBA $^{\mathrm{PR}}$ : PROG relative binding affinity; BET: betamethasone; $\mathrm{MF}$ : mometasone furoate; MO: mometasone; FP: fluticasone propionate; BMP: beclomethasone17-monopropionate; BECLO: beclomethasone; BUD: budesonide; TAA: triamcinolone acetonide. ${ }^{\#}$ : where $\mathrm{R}^{\prime}=$ furyl group. Delta $1\left(\Delta^{1}\right)$ and Delta 4 $\left(\Delta^{4}\right)$ indicate the presence of the unsaturated double bond between $\mathrm{C} 1-\mathrm{C} 2$ and C4-C5, respectively; ${ }^{\prime}$ : refers to the structure in fig. 3b.

lower selectivity associated with higher $\log \mathrm{P}$ values of the steroid.

The data obtained in the present study showed that some of the inhaled glucocorticoids displayed reduced GR selectivity. MCGUiRE et al. [18] have shown that the presence of a free $\mathrm{OH}$ group at the $\mathrm{C} 17 \alpha$ position of the steroid dramatically reduces the ability of the steroid to bind to the PR compared with the corresponding substituted esters at $\mathrm{C} 17 \alpha$. Similarly, the current experiments with $\mathrm{C} 17 \alpha-\mathrm{OH}$-containing glucocorticoids, such as DEX, BET, MO (a minor metabolite of MF) and BECLO, also showed decreased affinities towards the PR, while $\mathrm{C} 17 \alpha$ substituted lipophilic derivatives showed reduced selectivity.

The present results indicate that presence of a $\beta-\mathrm{CH}_{3}$ group, as in BET, increased GR selectivity over DEX. The difference in the orientation of C16 methyl group between DEX and BET indicates that a methyl group in the $\beta$ plane at $\mathrm{C} 16$ position of the steroid might sterically hinder favourable van der Waals interaction with the surrounding hydrophobic residues at the PR. Similarly, greater GR selectivity of BECLO compared with MO could be due to the differences in the $\beta$ orientation of the C16 methyl group, but also the C21 substitute in BECLO. The effect of $\beta$-alkyl substitution on the relative receptor affinity of steroids at the PR, as observed from the present experiment, were in agreement with the previous observations by MCGUIRE et al. [18].

Esterification of the $\mathrm{C} 17 \alpha \mathrm{OH}$ group in BMP and MF significantly increased the PR binding affinities and contributed to an overall decrease in the GR selectivities. The current data suggest that the furoate ester decreased GR selectivity much more than the propionate ester (as in BMP or FP).

The increase in affinity for lipophilic 16, 17-substituted glucocorticoids to GR has been related to the specific interaction of these derivatives with residues of the "lipophilic 
a)

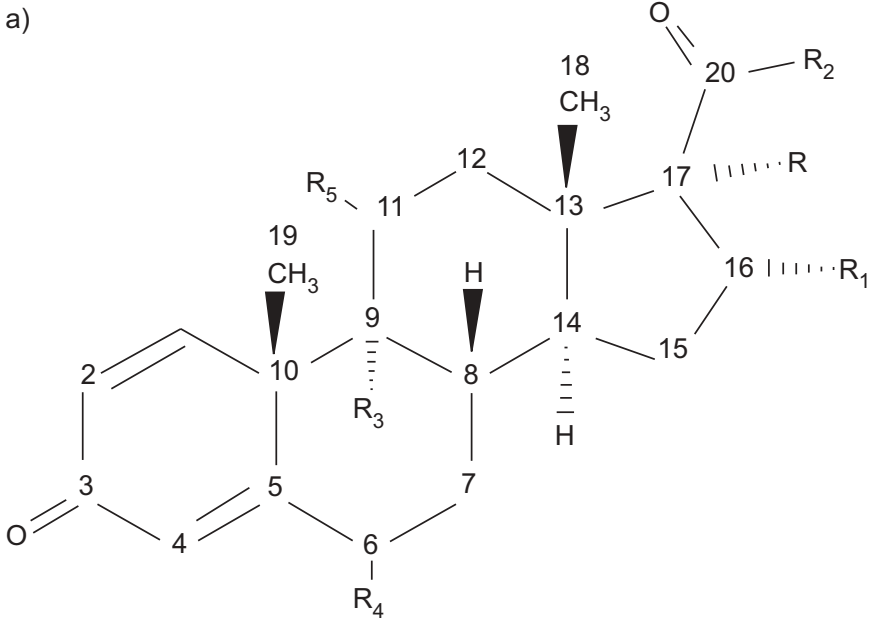

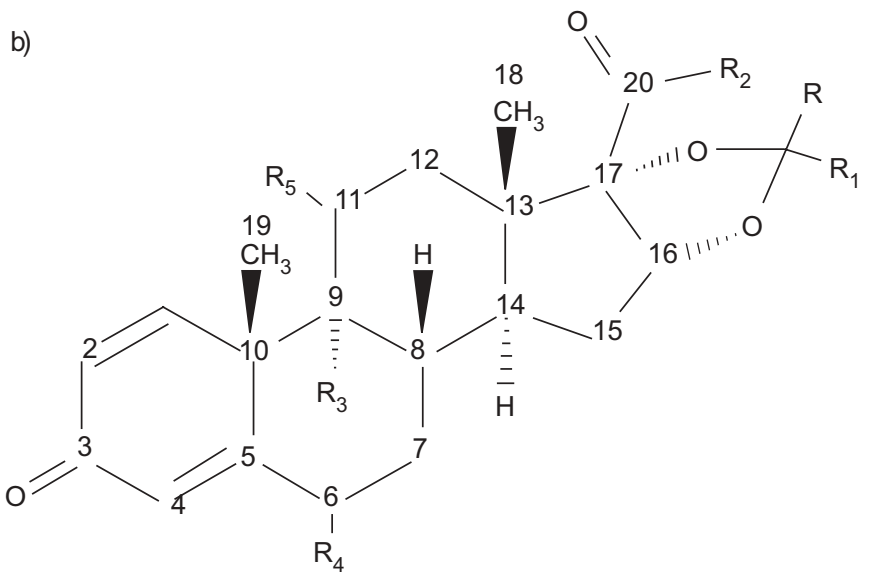

FIGURE 3. Chemical structures of various glucocorticoids and metabolites The corresponding $\mathrm{R}$ groups are given in table 2 . The bonds indicated by dotted arrows represent $\alpha$-orientation where the bond is below the plane of paper. Bonds indicated by solid lines represent $\beta$-orientation, with the bond being above the plain of paper

side pocket" of the GR [10]. The extra binding pocket present in the GR is absent in the PR. Therefore, the present authors were somewhat surprised that with increasing size (and lipophilicity), these derivatives showed a steeper increase in receptor affinity towards PR than towards GR. The AM1optimised structure (structure with optimised geometry) of MF was superimposed on the receptor-bound conformation of the original PROG ligand in its receptor as determined in the crystal structure [8]. Figure 4 indicates that the $C 17 \alpha$ side chain of MF can easily fit within the ligand-binding domain of PR, where it is mainly surrounded by hydrophobic residues (e.g. $\mathrm{Leu}^{715}$, Leu ${ }^{718}$, Phe ${ }^{794}$, Leu ${ }^{797}$ and $\mathrm{Tyr}^{890}$ ). The side chain encounters only some minimal structural hindrance from these residues, which could easily rearrange into a more convenient conformation as there is sufficient space and the receptor itself is also somewhat flexible [19]. The van der Waals interactions between the lipophilic $\mathrm{C} 17 \alpha$ ester substitution (as in MF) and the surrounding hydrophobic residues may, therefore, result in sufficiently favourable interactions to justify an increased binding affinity towards the PR. Possibly, a greater lipophilicity of the furoate substitution compared with the propionate might favour greater van der Waals interactions with

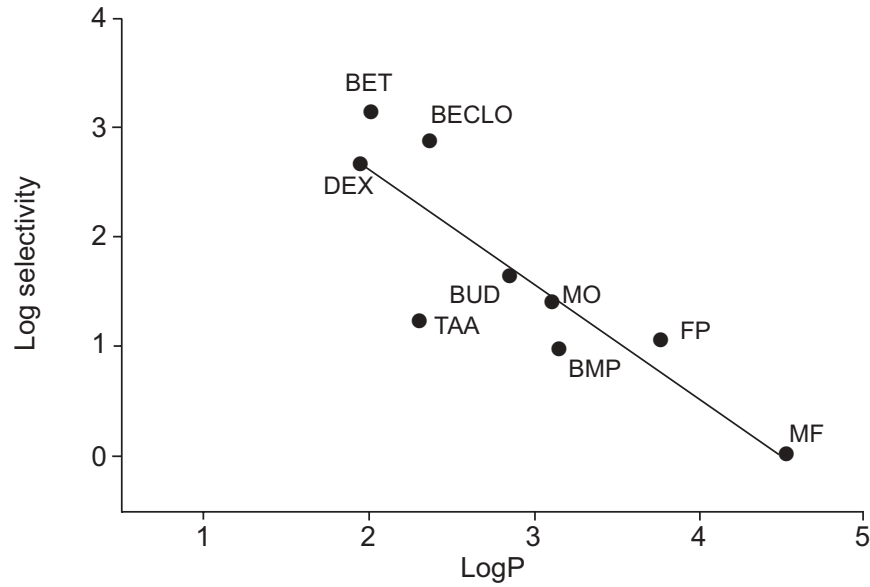

FIGURE 4. Relationship between the lipophilicity and the glucocorticoid receptor versus progesterone receptor selectivity of different steroids. The solid line represents the line of best fit (linear regression) through all data points. LogP correlates well with the observed log selectivity. BET: betamethasone; BECLO: beclomethasone; DEX: dexamethasone; BUD: budesonide; TAA: triamcinolone acetonide; MO: mometasone; BMP: beclomethasone-17-monopropionate; FP flucticasone propionate; MF: mometasone furoate. $R^{2}=0.7499$.

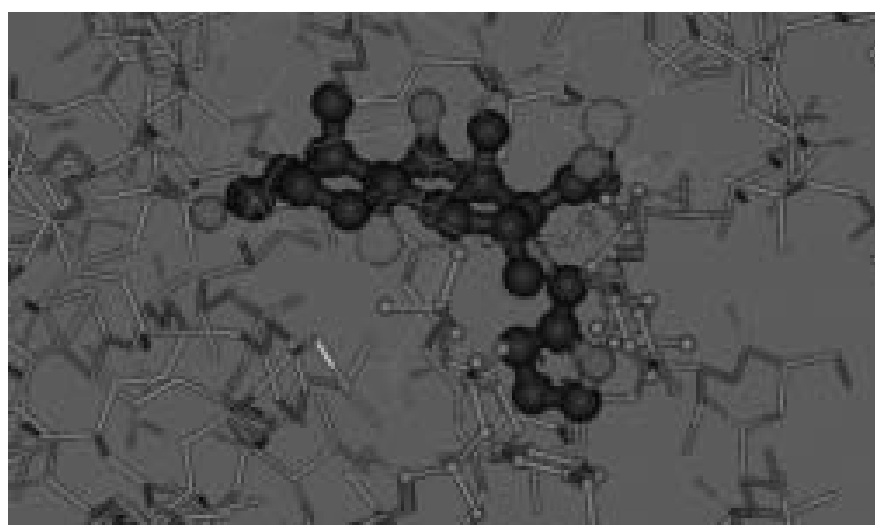

FIGURE 5. The structure of mometasone furoate shown as a dark ball-andstick structure. This is superimposed over that of progesterone bound to the ligandbinding domain of the human progesterone receptor. There is sufficient space to accommodate the $17 \alpha$ side chain, which is surrounded by hydrophobic residues (Leu $^{715}$, Leu $^{718}$, Phe $^{794}$, Leu ${ }^{797}$ and Tyr ${ }^{890}$; also shown as a ball-and-stick structure), which can provide favourable van der Waals interactions. Amino acid residues in front of the ligand are shown only as line structures so as not to hinder the view.

surrounding hydrophobic residues and a higher affinity. A recent paper by MADDAUs et al. [20] confirmed that the PR can indeed easily accommodate the larger side chain of MF and similar drugs by shifting the hydrophobic residues (e.g. Leu ${ }^{715}$, $\mathrm{Leu}^{718}$, Phe ${ }^{794}$, Leu ${ }^{797}$ and $\mathrm{Tyr}^{890}$ ) outward and increasing the binding pocket volume from $565 \AA^{3}$ for PROG to $730 \AA^{3}$ for MF.

The present data indicate that reduced size and lipophilicity in the 16, 17 region of the molecule reduces the interaction with surrounding hydrophobic residues (e.g. Leu ${ }^{715}, \mathrm{Leu}^{718}$, Phe ${ }^{794}$, $\mathrm{Leu}^{797}$ and $\mathrm{Tyr}^{890}$ ) and reduces affinity toward PR. The superimposition of BUD over PROG in PR (fig. 5) shows that despite sufficient space within the receptor to accommodate 


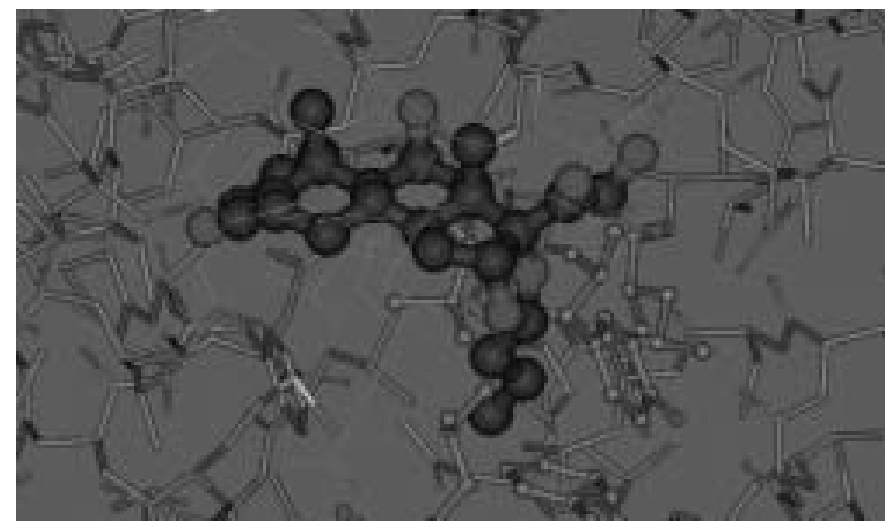

FIGURE 6. The structure of $R$-budesonide shown as a dark ball-and-stick structure is superimposed over that of the progesterone bound to the ligandbinding domain of the human progesterone receptor. The hydrophilic $\mathrm{C} 16 \alpha-\mathrm{O}$ in budesonide "bumps" a hydrophobic Leu ${ }^{797}$ and the hydrophilic $\mathrm{C} 21-\mathrm{OH}$ "bumps" a hydrophobic Ph905 residue of the progesterone receptor. The structures of surrounding hydrophobic residues (Leu ${ }^{715}, \mathrm{Leu}^{718}, \mathrm{Phe}^{794}$, $\mathrm{Leu}^{797}$ and $\mathrm{Tyr}^{890}$ ) are also shown as ball-and-stick structures that can provide favourable van der Waals interactions. Amino acid residues in front of the ligand are shown only as line structures so as not to hinder the view.

the side chains, the hydrophilic $\mathrm{C} 16 \alpha-\mathrm{O}$ and $\mathrm{C} 21-\mathrm{OH}$ groups experience minor hindrance from the surrounding hydrophobic residues Phe905 and Leu ${ }^{797}$, respectively. These unfavourable interactions at the $\mathrm{C} 21$ and $\mathrm{C} 16 \alpha$ side chains might also contribute to the worsening of the overall receptor fit of steroids with such side chains (e.g. BUD, TAA) at PR, resulting in a greater selectivity for BUD compared with MF and the propionate esters BMP and FP.

In conclusion, the present results indicate that the inhaled glucocorticoid mometasone furoate is the least specific followed by beclomethasone-17-monopropionate, flucticasone propionate, triamcinolone acetonide, mometasone and budesonide, which shows the highest glucocorticoid receptor versus progesterone receptor selectivity among inhaled corticosteroids. Less lipophilic glucocorticoids, substituted in position 16 with small methyl groups (dexamethasone, betamethasone, beclomethasone), showed higher selectivity. However, these systemically given drugs are used at much higher concentrations and, therefore, should not represent an advantage. Systemic side-effects associated with high systemic levels are also a major concern during high dose inhaled corticosteroid therapy. Steroids, such as mometasone furoate, that show sufficient cross-reactivity with progesterone receptors [4], could aggravate these systemic side-effects. Whether the systemic drug concentrations achieved among patients would be sufficient enough to identify any clinically relevant differences in selectivity among inhaled glucocorticoids remains to be shown in a therapeutic trial setting.

\section{REFERENCES}

1 Raynaud JP, Ojasoo T, Bouton MM, Philibert D. Receptor binding as a tool in the development of new bioactive steroids. In: EJ Ariens, ed. Drug Design. Vol 8. New York, Academic Press, 1979; pp. 169-214.
2 Kontula K, Paavonen T, Luukkainen T, Andersson LC. Binding of progestins to the glucocorticoid receptor. Correlation to their glucocorticoid-like effects on in vitro functions of human mononuclear leukocytes. Biochem Pharmacol 1983; 32: 1511-1518.

3 Evans RM. Molecular characterization of the glucocorticoid receptor. Recent Prog Horm Res 1989; 45: 1-27.

4 Austin RJ, Maschera B, Walker A, et al. Mometasone furoate is a less specific glucocorticoid than fluticasone propionate. Eur Respir J 2002; 20: 1386-1392.

5 Rohdewald P, Moellmann HW, Hochhaus G. Affinities of glucocorticoids for glucocorticoid receptors in the human lung. Agents and Actions 1985; 17: 290-291.

6 Buchwald P, Bodor N. Soft glucocorticoid design: structural elements and physicochemical parameters determining receptor-binding affinity. Pharmazie 2004; 59: 396-404.

7 Buchwald P, Bodor N. Octanol-water partition: searching for predictive models. Curr Med Chem 1998; 5: 353-380.

8 Williams SP, Sigler PB. Atomic structure of progesterone complexed with its receptor. Nature 1998; 393: 392-396.

9 Matias PM, Donner P, Coelho R, et al. Structural evidence for ligand specificity in the binding domain of the human androgen receptor. Implications for pathogenic gene mutations. J Biol Chem 2000; 275: 26164-26171.

10 Bledsoe RK, Montana VG, Stanley TB, et al. Crystal structure of the glucocorticoid receptor ligand binding domain reveals a novel mode of receptor dimerization and coactivator recognition. Cell 2002; 110: 93-105.

11 Dewar MJS, Zoebisch EG, Healy EF, Stewart JJP. AM1: a new general purpose quantum mechanical molecular model. J Am Chem Soc 1985; 107: 3902-3909.

12 Wurthwein G, Rehder S, Rohdewald P. Lipophilicity and receptor affinity of glucocorticoids. Pharm Ztg Wiss 1992; 5: 137.

13 Rohdewald P, Moellmann H, Mueller KM, Hochhaus G. Glucocorticoid receptors in the respiration tract. Munich, Verlag Gedon \& Reuss, 1985; pp. 223-242.

14 Ojasoo T, Dore JC, Gilbert J, Raynaud JP. Binding of steroids to the progestin and glucocorticoid receptors analyzed by correspondence analysis. J Med Chem 1988; 31: 1160-1169.

15 Hogger P, Rohdewald P. Binding kinetics of fluticasone propionate to the human glucocorticoid receptor. Steroids 1994; 59: 597-602.

16 Isogai M, Shimizu H, Esumi Y, Terasawa T, Okada T, Sugeno K. Binding affinities of mometasone furoate and related compounds including its metabolites for the glucocorticoid receptor of rat skin tissue. J Steroid Biochem Mol Biol 1993; 44: 141-145.

17 Wuerthwein G, Rehder S, Rohdewald P. Lipophilicity and receptor affinity of glucocorticoids. Pharm Ztg Wiss 1992; 137: 161-165.

18 McGuire JL, Bariso CD, Shroff AP. Interaction between steroids and a uterine progestogen specific binding macromolecule. Biochemistry 1974; 13: 319-322.

19 Teague SJ. Implications of protein flexibility for drug discovery. Nat Rev Drug Discov 2003; 2: 527-541.

20 Madauss KP, Deng SJ, Austin RJ, et al. Progesterone receptor ligand binding pocket flexibility: crystal structures of the norethindrone and mometasone furoate complexes. J Med Chem 2004; 47: 3381-3387. 